\title{
EVALUASI TEPUNG DAUN KATUK SEBAGAI FEED ADDITIF PADA PRODUKTIFITAS AYAM PETELUR
}

\author{
Effects of Katuk Leaf Meal as Feed Additive on Laying Hen Performances
}

\author{
Yuli Indriani1 ${ }^{1)}$, Eko Widodo ${ }^{2)}$, dan M. Halim Natsir ${ }^{2)}$ \\ ${ }^{1)}$ Mahasiswa Minat Nutrisi dan Makanan Ternak, Fakultas Peternakan, Universitas Brawijaya Jalan Veteran, \\ Ketawanggede, Kec. Lowokwaru, Kota Malang, Jawa Timur 65145 \\ 2) Dosen Minat Nutrisi dan Makanan Ternak, Fakultas Peternakan, Universitas Brawijaya Jalan Veteran, \\ Ketawanggede, Kec. Lowokwaru, Kota Malang, Jawa Timur \\ Corresponding email: emhanatsir@ub.ac.id
}

\begin{abstract}
ABSTRAK
Penelitian ini dilaksanakan di peternakan ayam petelur Talang Farm KUD Sari Bumi Desa Talang Suko, Kecamatan Turen, Kabupaten Malang pada tanggal 23 Januari sampai 26 Februari 2009. Tujuan dari penelitian ini unutk mengetahui pengaruh penambahan tepung daun katuk (Sauropus androgynus L. Merr) atau TDK dalam pakan ayam penyelur terhadap penampilan produksi ayam petelur. Materi yang digunakan dalam penelitian ini adalah ayam petelur Strain Isa Brown umur 66-69 minggu produksi PT. Anwar Sierad sebanyak 100 ekor. Metode yang digunakan dalam penelitian ini adalah Rancangan Acak Lengkap $(R A L)$ dengan 4 perlakuan antara lain pakan basal tanpa penambahan TDK $\left(P_{0}\right)$, Pakan basal $+1,5 \%$ TDK $\left(P_{1}\right)$, pakan basal $+3,0 \%$ TDK $\left(P_{2}\right)$, pakan basal $+4,5 \%$ TDK $\left(P_{3}\right)$. Masing-masing perlakuan diulang $5 \mathrm{kali}$, sehingga terdapat 20 unit percobaan dan setiap 1 unit percobaan terdiri dari 5 ekor ayam petelur. Variabel yang diamati antara lain konsumsi pakan (g/ekor/hari) Hen Day Production (\%), Egg mass (g/ekor/hari), konversi pakan dan Income Over Feed Cost (Rp). Data hasil penelitian ini diolah secara statistik dengan menggunakan Rancangan Acak Lengkap (RAL). Apabila ada perbedaan pengaruh diantara perlakuan,maka akan dilanjutkan dengan Uji Jarak Berganda Duncan's. Hasil penelitian menunjukkan bahwa penambahan TDK dalam pakan dengan persentase $0-4,5 \%$ memberikan perbedaan pengaruh yang tidak nyata $(P>0,05)$ terhadap konsumsi pakan (g/ekor/hari), Hen Day Production (\%), Egg mass (\%) dan konversi pakan sedangkan pada penambahan TDK sebesar 1,5\% dalam pakan ayam petelur dapat memberikan pengaruh yang lebih baik jika dibandingkan perlakuan lainnya.
\end{abstract}

Kata kunci: Tepung daun katuk,pakan,penampilan produksi,ayam petelur.

How to Cite:

Indriani, Y., Widodo, E., \& Natsir, M. H. (2019). Evaluasi Tepung Daun Katuk Sebagai Feed Additif pada Produktifitas Ayam Petelur. Jurnal Nutrisi Ternak Tropis 2 (2) 73-79
*Corresponding author:

M. Halim Natsir

Email: emhanatsir@ub.ac.id

Fakultas Peternakan, Universitas Brawijaya Jalan Veteran, Ketawanggede, Kec. Lowokwaru, Kota Malang, Jawa Timur 65145 


\section{ABSTRACT}

This experiment was carried out at Talang Farm KUD Sari Bumi in Talang Suko,Turen district, Malang Regency From Jan $23^{\text {th }}$ to Feb 26 $6^{\text {th }} 2009$. The purpose of this research was to observe effects of (Sauropus androgynus L. Merr) leaf meal addition on laying hen performance. A total of one hundred hens od Isa Brown Strain from 65 to 69 week of age were randomly allotted to four dietary treatments with 5 replication groups of 5 hens. Dietary treatment were: Basal diet $\left(T_{0}\right)$, basal diet $+1,5 \% \mathrm{TDK}\left(\mathrm{T}_{1}\right)$, basal diet $+3.0 \% \mathrm{TDK}$ $\left(T_{2}\right)$, basal diet $+4.5 \% \mathrm{TDK}\left(\mathrm{T}_{3}\right)$. The variables obeserved were feed intake (g/head/hari), Hen Day Production (\%), Egg mass (\%) and feed conversion. It can be concluded that Sauropus androgynus leaf meal addition on the laying hen at 1,5-4,5\% did not improve laying hen performances. The result of that research showed that the addition of TDK in feed with a percentage of $0-4.5 \%$ gave a significant difference in effect $(P>0.05)$ on feed consumption (g/head/day), Hen Day Production (\%), Egg mass (\%) and feed conversion while adding TDK of $1.5 \%$ in laying hens feed can have a better effect when compared to other treatments.

Key words: Sauropus androgynus leaf meal, feed, performance, laying hens.

\section{PENDAHULUAN}

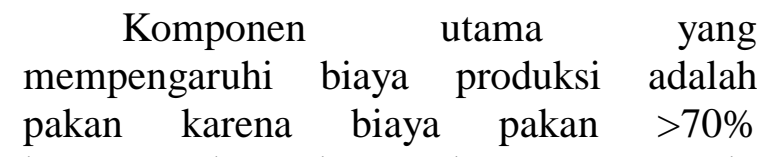
berpengaruh pada pendapatan peternak, sehingga pakan yang diberikan kepada ternak dapat mencukupi kebutuhan ternak serta harga yang murah. Harga bahan pakan yang mahal sering kali tidak diimbangi dengan kualitas pakan yang baik. Tingginya harga pakan menyebabkan usaha peternakan saat ini mendapatkan keuntungan yang rendah.

Alternatif yang dapat dilakukan yaitu melakukan penambahan tepung daun katuk (Sauropus androgynus L. Merr) dalam pakan petelur agar dapat memperbaiki kualitas ternak unggas (Letis, Agik dan Damina, 2017). Tepung daun katuk (Sauropus androgynus L. Merr) memiliki kelebihan yaitu kandungan protein kasar yang tinggi sebesar $28,85 \%$ dan energi bruto kandungan daun katuk ialah 38184939,64 (Subekti, 2008) serta meningkatkan ketebalan tubuh ternak terhadap penyakit, tidak mengandung racun bagi ternak maupun produksi hasil ternak. kandungan protein yang tinggi akan dimanfaatkan ternak untuk proses pembentukan telur dan sisanya untuk metabolisme basal, pertumbuhan badan dan bulu (Amrullah, 2003) selain itu menurut Santoso dkk (2018) menyatakan bahwa kandungan enam senyawa yang ada di dalam tepung katuk (Sauropus androgynus L. Merr) seperti methyl pyroglumate apabila dikonsumsi oleh unggas dapat meningkatkan sintesis asam amino dan sintesis protein.

Peningkatan sintesis protein dan AA ini membutuhkan energi yang cukup tinggi sehingga peranan lemak dalam tubuh ternak akan dirombak menjadi energi sehingga akan terjadi deposisi lemak. Hal ini akan menyebabkan peningkatan konsumsi protein ayam petelur sehingga meningkatkan produksi telur. Monomethyl succinate dan methyl cyclopentanol acetate diduga dapat dikonversikan menjadi succinate dan acetate. Pemberian acetate dan succinate dalam siklus kreb akan menghasilkan ATP yang lebih besar. Hal ini mengakibatkan tingkat efisiensi metabolisme energi menjadi lebih baik, karena tingginya efisiensi metabolisme akan meningkatkan efisiensi pakan (Santoso, 2012).

Santoso dan Sartini (2001) menemukan bahwa tingkat maksimal jika dilihat dari efisiensi pakan dan penurunan kadar lemak karkas dilakukan penambahan 
tepung daun katuk dalam pa kan ayam sebanyak 3\% dan menurunkan akumulasi lemak perut sebesar 3\%. Berdasarkan kajian diaatas maka peneliti tertarik untuk melakukan penelitian lebih lanjut dengan menggunakan ayam petelur yaitu mengenai pengaruh penambahan tepung daun katuk (Sauropus androgynus L. Merr) dalam pakan terhadap penampilan produksi ayam petelur.

\section{MATERI DAN METODE}

\section{Materi Penelitian}

Materi yang digunakan yaitu ayam Strain Isa Brown berumur 65-69 minggu sebanyak 100 ekor yang ditempatkan pada kandang battery. Pengamatan dilakukan selama 30 hari dengan Egg mass pada awal penelitian 57,20 \pm 4,99 (gram/ekor). Bahan pakan yang digunakan terdiri dari campuran jagung (52,23\%), bekatul $(12,25 \%)$, konsentrat ayam petelur (K-204 X-TRA) produksi PT. Sierad Produce (Sidoarjo) $(35,31 \%)$ dan customix $(0,21 \%)$. Bahan perlakuan TDK diperoleh dari Desa Besuki Kecamatan Suboh, Kabupaten Situbondo.

Prosedur pembuatan TDK yaitu daun katuk dikeringkan dibawah sinar matahari hingga kering kemudian digiling atau diblender hingga berbentuk tepung. Bentuk pakan yang diberikan yaitu mash yang diberikan 1 kali dalam sehari (dibatasi/penjatahan) sedangkan pemberian air secara adlibitum.

Tabel 1. Kandungan nutrisi bahan pakan basal dan bahan pakan perlakuan.

\begin{tabular}{|c|c|c|c|c|}
\hline \multirow{2}{*}{$\begin{array}{c}\text { Kandungan } \\
\text { Nutrisi }\end{array}$} & \multicolumn{4}{|c|}{ Bahan Pakan } \\
\hline & Konsentrat ${ }^{(1)}$ & Jagung $^{(2)}$ & Bekatul $^{(2)}$ & TDK* \\
\hline ME (Kkal/kg & 2147 & 3370 & 2860 & $3041,12^{(3)}$ \\
\hline PK (\%) & 35 & 8,6 & 10,2 & $28,85^{(4)}$ \\
\hline $\operatorname{LK}(\%)$ & 03 & 3,9 & 7,0 & $10,15^{(4)}$ \\
\hline SK $(\%)$ & 07 & 2,0 & 3,0 & $8,29^{(4)}$ \\
\hline $\mathrm{Abu}(\%)$ & 35 & 1,7 & 7,7 & $11,55^{(4)}$ \\
\hline Kalsium (\%) & 11 & 0,002 & 0,04 & $2,17^{(\mathbf{5})}$ \\
\hline Phospor (\%) & 01 & 0,1 & 0,16 & $0,66^{(\mathbf{5})}$ \\
\hline Keterangan: & $\begin{array}{l}{ }^{1} \text { Brosur PT. Sierad } \\
{ }^{2} \text { Wahyu (1997) } \\
{ }^{3} \text { Hasil dari perhitu } \\
{ }^{4} \text { Hasil analisis La } \\
\text { Brawijaya } \\
{ }^{5} \text { Hasil analisis L } \\
\text { Brawijaya } \\
{ }^{*} \text { TDK = Tepung D }\end{array}$ & $\begin{array}{l}\text { duce } \\
\text { an konversi } 75 \\
\text { ratorium kim } \\
\text { oratorium kin } \\
\text { Katuk }\end{array}$ & $\begin{array}{l}\text { Gross Energy be } \\
\text { tanah Fakultas } \\
\text { tanah Fakultas }\end{array}$ & $\begin{array}{l}\text { asarkan bahan kering } \\
\text { ternakan Universitas } \\
\text { ertanian Universitas }\end{array}$ \\
\hline
\end{tabular}

Tabel 2. Kandungan nutrisi pakan perlakuan berdasarkan \%BK

\begin{tabular}{cccccccc}
\hline Perlakuan & \multicolumn{7}{c}{ Kandungan Nutrisi \%BK } \\
\cline { 2 - 8 } & $\begin{array}{c}\mathrm{EM} \\
(\mathrm{Kkal} / \mathrm{kg})\end{array}$ & $\% \mathrm{PK}$ & $\% \mathrm{LK}$ & $\% \mathrm{SK}$ & $\%$ Abu & Kalsium $(\%)$ & $\begin{array}{c}\text { Phospor } \\
(\%)\end{array}$ \\
\hline $\mathrm{P}_{0}$ & 2707,37 & 20,29 & 5,54 & 4,91 & 14,06 & 4,1 & 0,61 \\
$\mathrm{P}_{1}$ & 2712,30 & 20,42 & 5,61 & 4,96 & 14,02 & 4,07 & 0,61 \\
$\mathrm{P}_{2}$ & 2717,09 & 20,54 & 5,68 & 5,01 & 13,99 & 4,04 & 0,61 \\
$\mathrm{P}_{3}$ & 2721,74 & 20,66 & 5,78 & 5,06 & 13,95 & 4,01 & 0,61 \\
\hline
\end{tabular}

Keterangan: ${ }^{1}$ Hasil analisis laboratorium Nutrisi dan Makanan Ternak Fakultas Peternakan Universitas Brawijaya

2 Kandungan nutrisi berdasarkan dari Hasil perhitungan pakan basal dan tepung daun katuk (Sauropus androgynus L. Merr) 


\section{Metode Penelitian}

Metode percobaan yang dilakukan adalah Rancangan Acak Lengkap (RAL) 4 x 5 yang artinya 4 perlakukan dan 6 kali ulangan sehingga total 20 unit percobaan, masing-masing unit percobaan mengunakan 5 ekor ayam sehingga total ayam yang digunakan 100 ekor. Perlakuan yang diberikan terdiri dari

$$
\begin{aligned}
\mathrm{P} 0= & \text { Pakan basal } \\
\mathrm{P} 1= & \text { Pakan basal dengan penambahan } 1,5 \\
& \% \text { TDK } \\
\mathrm{P} 2= & \text { Pakan basal dengan penambahan } 3,0 \\
& \% \text { TDK } \\
\mathrm{P} 3= & \text { Pakan basal dengan penambahan } 4,5 \\
& \% \text { TDK }
\end{aligned}
$$

\section{Variabel Penelitian}

Variabel yang diamati yaitu

1. Konsumsi pakan (g/ekor/hari) adalah angka rataan jumlah pakan yang diberikan dikurangi sisa pakan yang diukur setiap hari selama penelitian (Marhiyanto, 2000)
2. produksi telur harian atau Hen Day Production dihitung setiap hari dengan satuan yang digunakan adalah \% (Kurniawan, 2011)

$$
\mathrm{HDP}=\frac{\Sigma \text { Produksi telur hari itu (butir) }}{\Sigma \text { ayam yang ada }} \times 100 \%
$$

3. Egg mass adalah rata-rata berat telur harian yang diproduksi per hari per ayam.

4. Konversi pakan merupakan angka yang menunjukkan kemampuan ternak untuk mengubah sejumlah pakan menjadi setiap $\mathrm{kg}$ produksi. Konversi ini menunjukkan efisiensi penggunaan pakan ditinjau dari efisiensi teknis. Konversi pakan dihitung setiap minggu.

$$
\text { Konversi pakan }=\frac{\text { konsumsi pakan }(\mathrm{kg})}{\text { produksi telur total }(\mathrm{kg})}
$$

\section{HASIL DAN PEMBAHASAN}

Hasil perlakuan terhadap variabel yang diuji tersajikan pada Tabel 3 .

Tabel 3. Pengaruh perlakuam terhadap konsumsi pakan, HDP, Egg mass dan koversi pakan ayam petelur

\begin{tabular}{ccccc}
\hline Perlakuan & \multicolumn{4}{c}{ Variabel yang diamati } \\
\cline { 2 - 5 } & $\begin{array}{c}\text { Konsumsi Pakan } \\
\text { (g/ekor/hari) }\end{array}$ & $\begin{array}{c}\text { Hen Day } \\
\text { Production }(\%)\end{array}$ & $\begin{array}{c}\text { Egg mass } \\
\text { (g/ekor/hari) }\end{array}$ & $\begin{array}{c}\text { Konversi } \\
\text { Pakan }\end{array}$ \\
\hline $\mathrm{P}_{0}$ & $119,05 \pm 0,51$ & $82,29 \pm 3,89$ & $54,40 \pm 2,55$ & $2,20 \pm 0,12$ \\
$\mathrm{P}_{1}$ & $119,13 \pm 0,80$ & $86,71 \pm 6,28$ & $57,07 \pm 4,50$ & $2,11 \pm 0,17$ \\
$\mathrm{P}_{2}$ & $118,78 \pm 1,11$ & $83,43 \pm 4,88$ & $54,62 \pm 2,63$ & $2,19 \pm 0,01$ \\
$\mathrm{P}_{3}$ & $118,16 \pm 1,36$ & $84,14 \pm 6,09$ & $55,06 \pm 4,65$ & $2,17 \pm 0,19$ \\
\hline
\end{tabular}

\section{Pengaruh Perlakukan terhadap Konsumsi Pakan}

Berdasarkan data pada Tabel 3. Penambahan TDK pada ransum memiiliki nilai yang lebih tinggi dari pada perlakukan kontrol hal ini dapat disebabkan karena pakan yang diberikan penambahan daun katuk dapat memberikan perubahan warna hijau pada ransum sehingga ternak lebih menyukai (Saragih, 2016). Hasil analisis statistika menyatakan penambahan daun kauk dalam ransum memberikan pengaruh tidak nyata $(\mathrm{P}>0,05)$ terhadap konsumsi pakan sehingga pada setiap perlakuan dengan penambahan TDK memberikan efek yang sama, hal ini terlihat dari hasil konsumsi pakan disetiap perlakuan memiliki nilai yang relatif sama. Niai konsumsi pada ternak unggas dipengaruhi oleh kandungan energi dan protein sehingga kemungkinan dengan penambahan TDK sebanyak 4,5\% tidak memberikan pengaruh terhadap kandungan energi dan protein dalam pakan.

Hasil penelitian yang dilakukan tidak sesuai jika dibandingkan dengan hasil Santoso dan Sartini (2001) yang menyatakan bahwa pakan ayam pedaging 
yang diberi perlakuan penambahan 3\% TDK menghasilkan konsumsi pakan yang lebih rendah dan konversi pakan yang lebih baik $(\mathrm{P}<0.05)$ dari pada ayam yang diberi pakan kontrol.

Perbedaan dari hasil penelitian ini dipengaruhi oleh faktor lingkungan yaitu spesies ayam, suhu, temperatur dan lokasi penelitian. Konsumsi pakan yang tidak berbeda nyata antar perlakuan mengindikasikan bahwa meskipun konsumsi cenderung menurun jika TDK diberikan lebih dari $1,5 \%$ dalam pakan tetapi level 4,5\% masih bisa ditolerir oleh ayam petelur. Konsumsi pakan yang cenderung menurun antar perlakuan jika TDK digunakan lebih dari $1,5 \%$ seperti $\mathrm{P}_{2}$ dan $\mathrm{P}_{3}(118,78 \pm 1,11$ dan $118,16 \pm 1,36)$ yaitu perlakuan dengan penambahan TDK $3,0 \%$ dan 4,5\% disebabkan oleh adanya kandungan tannin dan saponin dalam TDK (Santoso dkk, 2001).

Kandungan saponin dan tannin yang terdapat dalam daun katuk dapat menimbulkan bau sehingga dapat menurunkan palatabilitas pakan. Konsumsi pakan dipengaruhi oleh kandungan energi, serat kasar, lemak kasar dan kerapatan jenis pakan.

\section{Pengaruh Perlakukan terhadap HDP}

Hasil penelitian pada Tabel 4. Menunjukkan rata-rata HDP perlakuan lebih tinggi jika dibandingkan dengan perlakuan kontrol. Nilai HDP tertinggi dari $\mathrm{P}_{1}$ dengan nilai $86,71 \pm 6,28 \%$ dan nilai HDP terendah dari $\mathrm{P}_{0}$ dengan nilai 82,29 \pm $3,89 \%$. Hal ini mengindikasikan bahwa penambahan TDK memberikan efek yang positif terhadap HDP, namun hasil statistika menyatakan bahwa hasil penelitian dengan penambahan TDK memberikan pengaruh yang tidak nyata $(\mathrm{P}>0,05)$ terhadap HDP. Hasil ini didukung oleh hasil rata-rata konsumsi pakan yang tidak memberikan perbedaan nyata dan kandungan nutrisi yang cenderung sama antar perlakuan seperti yang tertera pada Tabel 4.

Oleh karena itu hal tersebut tidak memberikan pengaruh terhadap produksi telur karena konsumsi pakan menentukan tinggi rendahnya produktivitas ternak. Pakan yang diberikan mengandung zat nutrisi yang dibutuhkan ternak, apabila konsumsi protein dan energi dalam pakan rendah maka secara fisiologis kebutuhan ternak tidak terpenuhi dan hasil produktivitasnya tidak optimal.

Tabel 4. Konsumsi Protein dan energi pada ayam petelur selama penelitian

\begin{tabular}{cccc}
\hline \multirow{3}{*}{ Perlakuan } & \multicolumn{3}{c}{ Konsumsi } \\
\cline { 2 - 4 } & Pakan (g/ekor/hari) & $\begin{array}{c}\text { Energi } \\
\text { (Kkal/ekor/hari) }\end{array}$ & $\begin{array}{c}\text { Protein } \\
\text { (g/ekor/hari) }\end{array}$ \\
\hline $\mathrm{P}_{0}$ & $119,05 \pm 0,51$ & 322,31 & 24,15 \\
$\mathrm{P}_{1}$ & $119,13 \pm 0,80$ & 323,12 & 24,33 \\
$\mathrm{P}_{2}$ & $118,78 \pm 1,11$ & 322,74 & 24,39 \\
$\mathrm{P}_{3}$ & $118,16 \pm 1,36$ & 321,60 & 24,41 \\
\hline
\end{tabular}

Adanya kecenderungan peningkatan HDP dengan penambahan TDK dalam pakan ayam petelur diduga disebabkan oleh kandungan senyawa aktif yang terdapat dalam daun katuk (Sauropus androgynus L. Merr) seperti methly pyroglumate jika dikonsumsi oleh unggas akan terjadi peningkatan sintesis protein dan asam amino. Dengan adanya peningkatan sintesis asam amino dan sintesis protein maka nilai nutrisi protein ayam petelur akan semakin tinggi, sehingga hal tersebut dapat meningkatkan produksi telur.

\section{Pengaruh Perlakukan terhadap Egg mass}

Berdasarkan Tabel 4. Terlihat bahwa penambahan TDK terhadap Egg mass mempu meningkatkan Egg mass dengan nilai tertinggi pada $\mathrm{P}_{1}$ dengan nilai $57,07 \pm$ 4,5 g/ekor dan nilai terendah pada $\mathrm{P}_{0} 54,4 \pm$ 
2,25 g/ekor. Hal ini mengindikasikan bahwa semakin tinggi HDP akan semakin besar Egg mass. Hasil analisis statistika menunjukkan pengaruh yang tidak nyata $(\mathrm{P}>0,05)$ terhadap Egg mass yang kemungkinan disebabkan oleh konsumsi pakan karena total nutrisi yang dikonsumsi dalam pakan akan berpengaruh terhadap produksi telur. Nilai konsumsi pakan yang cenderung sama antar perlakuan seperti jumlah konsumsi protein, dan energi yang tertera pada Tabel 4 tidak memberikan pengaruh terhadap Egg mass.

Nilai Egg mass akan cenderung meninngkat dengan penambahan TDK yang tertera di Tabel 3. Kemungkinan disebabkan oleh kandungan methlyl pyroglumate dalam daun katuk yang diduga mempengaruhi produksi telur (Santoso dkk, 2008). Dengan produksi telur yang meningkat maka Egg mass juga akan meningkat, walaupun konsumsi pakan dan kandungan nutrisi baik energi, protein dan kalsium pada masing-masing pakan perlakuan relatif sama.

\section{Pengaruh Perlakukan terhadap Konversi Pakan}

Nilai konversi pakan hasil penelitian menunjukkan adanya kecenderungan penurunan dengan penambahan TDK, dimana konversi pakan tertinggi dari $\mathrm{P}_{0}$ dengan nilai 2,20 $\pm 0,12$ dan nilai konversi pakan terendah dari $\mathrm{P}_{1}$ dengan nilai 2,11 \pm 0,17 . Semakin kecil nilai konversi pakan menunjukkan tingak efisiensi pakan yang tinggi atau optimal.

Hasil penelitian yang dilakukan dengan uji statistik menunjukkan bahwa penambahan TDK dalam pakan tidak memberikan pengaruh nyata $(\mathrm{P}>0,05)$ terhadap konversi pakan. konversi pakan merupakan nilai dari pembagian konsumsi pakan dengan berat telur yang dihasilkan pada suatu waktu tertentu. Hasil statistik ini sejalan dengan analisis statistik konsumsi pakan, HDP, Egg mass yang memberikan pengaruh tidak nyata. Hasil penelitian terhadap konversi pakan tidak sesuai dengan hasil penelitian yang dilakukan
Santoso dan Sartini (2001) dari hasil perlakuan dengan penggunaan $3 \%$ daun katuk dalam pakan ayam pedaging memberikan pengaruh yang nyata $(\mathrm{P}<0,05)$ terhadap konversi pakan dan memberikan efek yang lebih baik jika dibandingkan dengan ayam kontrol.

Perlakuan P1 menunjukkan nilai konversi pakan terbaik hal ini didukung oleh kecenderungan peningkatan yang sama pada HDP dan Egg mass yang diduga disebabkan oleh adanya senyawa aktif methyl pryoglumate yang terdapat dalam TDK yang diduga dpat mempengaruhi produksi telur sehingga hal tersebut dapat berpengaruh terhadap perhitungan nilai konversi pakan.

\section{KESIMPULAN}

Hasil penelitian ini dapat disimpulkan bahwa penambahan $1,5 \%$ tepung daun katuk (Sauropus androgynus L. Merr) didalam pakan ayam petelur Strain Isa Brown yang berumur 65 - 69 minggu dapat memperbaiki konsumsi pakan (g/ekor/hari), Hen Day Production (\%), Egg mass (\%) dan konversi pakan.

\section{DAFTAR PUSTAKA}

Amrullah, I. K. (2003). Nutrisi Ayam Petelur. Bogor: Satu Gunung Budi.

Kurniawan, H., Guntoro, B., \& (Wihandoyo), W. (2012). Strategi pengembangan ayam ras petelur di kota samarinda kalimantan timur. Buletin Peternakan, 35(1), 57-122. https://doi.org/10.21059/buletinpetern ak.v35i1.591

Letis, Z. M., Suprayogi, A., \& Ekastuti, D. R. (2017). Sediaan daun katuk dalam pakan ayam pedaging menurunkan lemak abdominal, kadar lemak, dan kolesterol daging. Jurnal Veteriner, 18(3), 461-468. https://doi.org/10.19087/jveteriner.201 7.18.3.461 
Marhiyanto, B. (2000). Sukses Beternak Ayam Arab. Difa Publisher.

Santoso, U. (2012). Pengaruh Ekstrak Daun Katuk sebagai Fed Supplemen terhadap Performa Ayam Broiler. Menuju Pertanian Berdaulat.

Santoso, U. (2018). Penggunaan Daun katuk (sauropus androgynus) sebagai suplemen pakan pada unggas. 1 . pengaruhnya terhadap performa ayam. Jurnal Sain Peternakan Indonesia, 13(2), 151-156. https://doi.org/10.31186/jspi.id.13.2.151-156

Santoso, U., \& Sartini. (2001). Reduction of fat accumulation in broiler chickens by Sauropus androgynus (Katuk) leaf meal supplementation. Asian-Aust. Jurnal Animal Science, 14, 346-350.
Santoso, U., Suharyanto, \& Kususiyah. (2008). Penggunaan Ekstrak Air Daun Katuk sebagai Pengganti Feed Additive Komersial untuk Memproduksi Meat and Egg Designers yang Efisien. Universitas Bengkulu.

Subekti, S., Sumartidan, S., \& Murdiarti, T. (2008). Pengaruh Daun Katuk (Sauropus androgynus (L.)Merr.) dalam Ransum terhadap Fungsi Reproduksi pada Puyuh. Jurnal Ilmu Ternak Veteriner, 13(3), 167-173.

Wahyu, J. (1997). Ilmu Nutrisi Unggas (4th ed.). Yogyakarta: Gadjah Mada University Press. 